\title{
Epidemiology of basal cell carcinoma
}

\author{
Epidemiologia do carcinoma basocelular
}

Valquiria Pessoa Chinem ${ }^{1}$

\author{
Hélio Amante Miot ${ }^{2}$
}

\begin{abstract}
Basal cell carcinoma is the most common malignant neoplasm in humans and its incidence has increased over the last decades. Its high frequency significantly burdens the health system, making the disease a public health issue. Despite the low mortality rates and the rare occurrence of metastases, the tumor may be locally invasive and relapse after treatment, causing significant morbidity. Exposure to ultraviolet radiation is the main environmental risk factor associated with its cause. However, other elements of risk are described, such as light skin phototypes, advanced age, family history of skin carcinoma, light eyes and blond hair, freckles in childhood and immunosuppression. Behavioral aspects such as occupational sun exposure, rural labor and sunburns at a young age also play a role. Between $30 \%$ and $75 \%$ of the sporadic cases are associated with patched hedgehog gene mutation, but other genetic changes are also described. The tumor is commonly found in concomitance with skin lesions related to chronic sun exposure, such as actinic keratoses, solar lentigines and facial telangiectasia. The prevention of basal cell carcinoma is based on the knowledge of risk factors, early diagnosis and treatment, as well as on the adoption of specific measures, particularly in susceptible populations. The authors present a review of the epidemiology of basal cell carcinoma.
\end{abstract}

Keywords: Injections, intradermal; Review; Skin; Therapeutics

\begin{abstract}
Resumo: O carcinoma basocelular é a neoplasia maligna mais comum em humanos e sua incidência vem aumentando nas últimas décadas. Sua grande frequência gera significativo ônus ao sistema de saúde, configurando problema de saúde pública. Apesar das baixas taxas de mortalidade e de rara ocorrência de metástases, o tumor pode apresentar comportamento invasivo local e recidivas após o tratamento, provocando importante morbidade. Exposição à radiação ultravioleta representa o principal fator de risco ambiental associado a sua gênese. Entretanto, descrevem-se outros elementos de risco: fotótipos claros, idade avançada, história familiar de carcinomas de pele, olhos e cabelos claros, sardas na infância e imunossupressão, além de aspectos comportamentais, como exercício profissional exposto ao sol, atividade rural e queimaduras solares na juventude. Entre $30 \%$ e $75 \%$ dos casos esporádicos estão associados à mutação do gene patched bedgehog, mas outras alterações genéticas são ainda descritas. A neoplasia é comumente encontrada concomitantemente com lesões cutâneas relacionadas à exposição solar crônica, tais como: queratoses actínicas, lentigos solares e telangiectasias faciais. A prevenção do carcinoma basocelular se baseia no conhecimento de fatores de risco, no diagnóstico e tratamento precoces e na adoção de medidas específicas, principalmente, nas populações susceptíveis. Os autores apresentam uma revisão da epidemiologia do carcinoma basocelular.

Palavras-chave: Injeções intradérmicas; Pele; Revisão; Terapêutica
\end{abstract}

\footnotetext{
Approved by the Editorial Board and accepted for publication on 29.04.2010.

* Work conducted at the Department of Dermatology and Radiotherapy, Faculty of Medicine of Botucatu, Sao Paulo State University (FMB-UNESP), Botucatu (SP), Brazil.

Conflict of interest: None / Conflito de interesse: Nenhum

Financial funding: None / Suporte financeiro: Nenbum

MSc - Dermatologist, Department of Dermatology and Radiotherapy, Faculty of Medicine of Botucatu, Sao Paulo State University (FMB-UNESP), Botucatu-SP, Brazil. $\mathrm{PhD}$ - Assistant Professor, Department of Dermatology and Radiotherapy, Faculty of Medicine of Botucatu, Sao Paulo State University (FMB-UNESP), Botucatu (SP), Brazil.

(C)2011 by Anais Brasileiros de Dermatologia
} 


\section{INTRODUCTION}

Basal cell carcinoma (BCC) is the most common malignant neoplasm in humans, especially in fair-skinned individuals. ${ }^{1-3}$ The cumulative risk of development of the disease throughout life in the German white population is over $30 \%$. It shows a locally invasive behavior and low metastatic potential and is easily treatable by surgical excision, as long as it is diagnosed early. Due to its frequency and sanitary relevance, there is a vast literature on its epidemiology. $3,5,6$

BCC was first described by Jacob in 1827, who called it "ulcus rodens"; its current nomenclature was proposed by Krompecher in $1903 .{ }^{7}$

No precursor lesions have been described for BCC and the cells involved in its origin are still a matter of some controversy. ${ }^{4.8}$ to ${ }^{10}$ Despite resembling the basal cell layer of the epidermis, there is evidence that these cells are derived from immature pluripotent cells of interfollicular epidermis and those present in the outer sheath of the hair follicle. ${ }^{11}$ This is based on experiments with activation of the hedgehog signaling pathway in different compartments of the epidermis and on the expression of cytokeratins 5, 14, 15, 17 and 19 with a follicular pattern, which has defined it as a malignant neoplasm of follicular germinative cells (trichoblasts).

${ }^{11}$ Furthermore, there is an association of BCC with abnormalities of the sonic hedgehog gene. ${ }^{12}$ This hypothesis is further strengthened by the rarity of palmoplantar and mucosal lesions, where no hair follicles are found. ${ }^{13.14}$

Exposure to ultraviolet radiation (UV) is the main risk factor associated with the genesis of BCC, as evidenced by a higher frequency of the disease in sunexposed areas, population frequencies related to latitude, association with photosensitive genetic disorders and by patterns of sun exposure among patients. There is also a higher incidence of BCC in African albinos than in blacks. The risk attributed to solar radiation for malignant keratinocytic neoplasms may reach $90 \% .{ }^{15.16}$

It is believed that the development of BCC occurs in a period of 10 to 50 years after sun damage. 4 Recreational exposure to high doses of UV rays in childhood and youth is a strong element of risk, as evidenced by studies of people who immigrated to low-latitude countries. These studies showed BCC rates similar to those of natives if immigration occurred before 10 years of age. ${ }^{1.17-19}$ Other studies have associated melanoma and BCC with intense acute sun exposure and sunburns before the age of 20 , which would triple the risk of BCC; chronic sun exposure is more important in the genesis of squamous cell carcinoma (SCC). ${ }^{1,9,20,21}$
However, the coexistence of BCC and actinic skin lesions as well as the increased risk of occupational chronic exposure to UV rays, such as that of farmers, also suggest the involvement of chronic exposure to UV rays in the development of BCC, with evidence of the existence of a plateau of cumulative chronic exposure, above which the risk of developing cancer appears not to increase. ${ }^{2.10}$

Probably, different patterns of sun exposure are independent risk factors for certain clinical and histological types, topographies and prognosis of these tumors, being the focus of controversy among researchers. Ethnic, cultural, and professional aspects may also interfere in the epidemiological patterns of BCC in different countries. For example, superficial BCCs are more recurrent and are associated with intermittent and intense exposure, while nodular types are more associated with chronic exposure. Pigmented BCC is more frequent in melanoderma patients. ${ }^{22.23}$

UVB radiation generates mutagenic photoproducts in DNA, such as cyclodipyrimidine dimers, and mutations in important genes which regulate cell functions such as the p53 tumor suppressor gene. Apoptosis of keratinocytes (sunburn cells) after exposure to UV rays is evidence of its carcinogenic potential. UVA rays have an indirect effect by generating cytotoxic and mutagenic free radicals, favoring the effects of UVB rays. In addition, UV rays have an immunosuppressive action on the skin, harming the local antitumor monitoring activity of dendritic cells. ${ }^{1,4,24-26}$

\section{FREQUENCY}

BCC is the most common skin malignancy and represents between $70 \%$ to $80 \%$ of these tumors. The proportion of occurrence in the population is four to five BCCs for each SCC, and eight to ten for each melanoma diagnosed. ${ }^{27}$ Registration of BCC is not compulsory in our country, and many studies combine cases of BCC and SCC in their reports .

The number of new cases of non-melanoma skin cancer estimated for Brazil in the year 2010 was approximately 115,000 , representing nearly $2.2 \%$ of dermatologic visits; the estimated risk is of 56 new cases per 100,000 men and 61 new cases per 100,000 women. ${ }^{28.29}$ However, the rates vary according to region and ethnic composition of the population, reaching 85 (cases/100,000 inhabitants) in the South and only 25 in Northern Brazil. These data can be translated into an annual estimate of about 90,000 BCCs in the country ${ }^{28}$

However, it is likely that these numbers have been underestimated, since non-excisional treatment 
techniques do not result in notification to anatomical pathology services, affecting the projections. This fact shows that the rate of non-melanoma skin cancer is even more important in our population than estimated by government agencies. ${ }^{28}$

The estimated annual incidence of BCC in the United States of America (USA) in 1996 was approximately 500,000 cases, while that of SCC was between 100,000 and 150,000. Together, the incidence of BCC and SCC was 18 times greater than that of melanoma. In 2002, about 900,000 Americans were diagnosed with BCC and in 2005, 1,000,000 patients received this diagnosis, showing an increase in frequency. ${ }^{30.31}$

In countries with a phenotypically lighterskinned population, the numbers are even higher. In Australia, the incidence of BCC is the world's largest, accounting for 726 cases $(100,000$ inhabitants/ year). In Germany, the incidence is 96 cases $(100,000$ inhabitants/year) for men and 95 ( 100,000 inhabitants/year) for women. In Canada, $87(100,000$ inhabitants/year) for men and $68(100,000$ inhabitants/year) for women. In Finland, 49 (100,000 inhabitants/ year) for men and $45(100,000$ inhabitants/ year) for women. In Switzerland, 52 $(100,000$ inhabitants/year) for men and $38(100,000$ inhabitants/year) for women. In the Netherlands, 53 $(100,000$ inhabitants/year) for men and $38(100,000$ inhabitants/ year) for women). ${ }^{9,32,33}$

The incidence and morbidity rates of BCC, SCC and melanoma have been increasing in recent decades at a rate of over $4 \%$ per year in all countries and social classes. It is estimated that approximately $50 \%$ of fair-skinned individuals over 60 years old will develop some type of skin cancer. ${ }^{1.34}$ to 38

In England, the incidence of BCC increased from 173.5 to 265.4 per 100,000 inhabitants / year in 10 years. In the white population in the U.S., Canada and Australia the annual increase has averaged $3.7 \%{ }^{8}$ In the U.S., it has doubled in 20 years. ${ }^{30}$ In Brazil, the growth rate of skin cancer increased about $113 \%$ between 2001 and $2006{ }^{39}$. In the Clinical Hospital of UNESP, Botucatu-SP, an absolute increase of $90 \%$ in the incidence of BCC was observed in the past 11 years, representing an increase of $61 \%$ compared with the number of hospital attendances for the period (unpublished data). With an annual growth rate of $10 \%, \mathrm{BCC}$ will soon surpass the incidence of all other malignancies combined. ${ }^{40}$

One hypothesis for this increase may be greater awareness of the population based on prevention campaigns, as well as greater attention from general practitioners to diagnosis and referral of patients. ${ }^{9.39}$ Other factors discussed are greater cumulative exposure to UV rays, time available for leisure (unprotected), popularity of tanned skin, ozone layer depletion ( $2 \%$ in the last 20 years), increased longevity and the proportion of elderly individuals in the population. ${ }^{8}$

Men are more affected than women (1,5-2:1), which is probably for professional reasons, and males are also associated with a greater number of tumors. 41 There are, however, some studies that suggest a recent increase in the proportion of female patients, including those who are less than 40 years of age, because most women seek dermatologic care. The role of tanning beds (odds ratio $=1.5$ ) and photoexposed leisure is described as a potential risk factor. Moreover, BCCs excised in women tend to have smaller diameters, suggesting greater health care and early medical attention. ${ }^{29,30,42,43}$

BCC occurs more often in the elderly. More than half of the cases occur between 50 and 80 years of age and the incidence of the disease increases with age. However, the age group affected is younger than that of SCC. ${ }^{9}$ An increasing incidence of BCC in individuals younger than 40 years has been observed, which already accounts for more than $5 \%$ of the diagnoses. BCC is rare in childhood and youth. The hypotheses for this phenomenon are not clear but appear to indicate intense recreational unprotected sun exposure, which can also be suggested by the fact that adolescents show more lesions on the trunk, of the superficial subtype, which relate more to this type of exposure. We also observed a trend toward higher incidence in more affluent classes. The habit of sunbathing is associated with a five-fold increased risk of development of BCC on the trunk. ${ }^{37,44,45}$

Still, a higher proportion of young women have been diagnosed with BCC, which may be associated, in addition to the above factors, with natural and artificial tanning in the last decades. ${ }^{30,37,46-49}$ The relationship between patterns of sun exposure, age of onset and histological aggressiveness of BCC is controversial among researchers; therefore, more epidemiological studies involving different population groups need to be conducted in an attempt to elucidate this matter. ${ }^{50.51}$

The most important constitutional risk factors for the development of BCC are: light phototypes (I and II by Fitzpatrick classification), positive family history of BCC (30-60\%), freckles in childhood, light skin, eyes or hair. Fair-skinned individuals are 10 to 20 times more likely to develop BCC than those with dark skin, even when they live in the same region. ${ }^{4,30,52,53}$

Moreover, BCC is rare in blacks, Orientals and Hispanics; there are reports that its incidence is lower in patients with a history of acne and oily skin. ${ }^{54.55}$ Blacks have a lower incidence of BCC in sun-exposed areas, but in unexposed areas the incidence is similar 
to that of whites, being the majority pigmented BCCs ( $>50 \%$ of pigmented lesions as compared with $6 \%$ in Caucasians). $1,8,9,55,56$

The most relevant behavioral and exposure factors are: unprotected professional exposure to UV rays (rural activity, fishermen and builders), sports and outdoor recreation, sunburns in youth, radiotherapy treatments, phototherapy (PUVA or UVB) and arsenic exposure. 1,2,20,41,53,54,57-65

Dark hair dye colors, diets rich in fat and artificial tanning beds have been suggested in some studies as factors associated with the development of BCC, but they need to be further clarified in other studies with their own specific designs. ${ }^{52,57,66}$

Prolonged use of photosensitizing drugs such as tetracyclines, sulfonamides, fluoroquinolones, phenothiazines, and diuretics was associated with risk of BCC in a study conducted in the USA. ${ }^{67}$

Exposure to paraffin, coal, tar (coaltar), pitch, industrial oils, agricultural chemicals, pesticides, ionizing radiation, chronic scarring (burns, discoid lupus, vaccines), and tattoos have been sporadically reported. ${ }^{4.68 \text { to } 72}$

Tobacco and alcohol use remains controversial; however, most authors did not find a significant association after adjustment for other risk factors. ${ }^{4,10,73-}$ 78

The intake of statins or antioxidants like vitamin $\mathrm{C}$, vitamin $\mathrm{E}$, carotenoids and selenium was not associated with risk of BCC; however, the role of flavonoids, polyphenols, zinc and vitamin $\mathrm{D}$ has not been fully explained. ${ }^{79-82}$

It was identified that elevated serum levels of vitamin $\mathrm{D}$ are associated with a risk of $\mathrm{BCC}$, but these levels may represent only a marker of unprotected sun exposure, rather than suggest a direct oncogenetic effect. ${ }^{83}$

The consumption of high daily doses of coffee ( $>6$ cups) was associated with a reduction of up to $30 \%$ in the prevalence of non-melanoma skin cancer in Caucasian women. Indeed, caffeine showed a photoprotective effect and reduced UVB-induced carcinogenesis by inducing apoptosis in the skin of mice. The same was observed in cultured keratinocytes, in which caffeine increased the potential of apoptosis by inhibiting the ATR-Chk1 pathway. ${ }^{52.84}$ to 86

BCC is most commonly found together with skin lesions associated with chronic sun exposure such as actinic keratoses on the face, actinic cheilitis, solar lentigines, facial telangiectasia, cutis romboidalis nuchae and Racouchot-Favre syndrome. 2,10,17,53,58 Paradoxically, solar elastosis has been described both as a risk marker and protection factor against BCC in different studies. ${ }^{10,18,58}$
Immunocompromised patients, those with AIDS or with a history of other BCC or other malignant skin tumors are more prone to the development of BCC. Transplant patients have an incidence 5 to 16 times higher than the general population; SCC affects 40 to 250 times more this group of patients. ${ }^{3,40,87}$

The occurrence of consecutive tumors is common, and recurrence is more common in the first year. In three years the risk of a patient with BCC to present with another injury ranges from $27 \%$ to $44 \%$, reaching $50 \%$ in five years. With each new tumor the risk of recurrence increases progressively. Patients with more than ten BCCs have more than a 90\% chance of presenting with a new lesion. Male patient, over 60 years of age, BCC located on the trunk, of the superficial type upon histological examination, and presence of multiple actinic keratoses on the skin are predictive factors for the emergence of new lesions. $1,4,27,35,88$

There are geographic variations in the incidence of BCC; the incidence is higher in low latitudes, such as in some regions of Australia $(1,600 / 100,000$ inhabitants per year) due to proximity to the Equator, than in Southern U.S. (300/100,000 inhabitants / year) and northern Europe (40$80 / 100,000$ inhabitants per year). ${ }^{1,4,89}$

\section{CLINICAL FORMS}

BCCs may have varying sizes. Lesions of a few millimeters can already be identified and, as they develop reaching up to several centimeters, clinical features become more evident. Oftentimes, however, differential diagnosis with other papulonodular and solitary ulcerated skin diseases is necessary. It is commonly referred to by patients as a wound that does not heal or an acne lesion due to its typical slow and asymptomatic growth.

They are clinically divided into five types: nodular-ulcerative, pigmented, sclerodermiform or fibrosing, superficial and fibroepithelioma, although there is disagreement with regard to the classification by some authors. ${ }^{9,27,90-93}$ The frequency of clinical forms differs among populations. An overview of the distributions in different studies is shown in Table 1.

The nodular ulcerative form is the most common, usually in isolation, affecting mainly the head and neck. It is characterized as a papule or nodule with a pearly aspect, often with typical telangiectasia seen on dermoscopy, which subsequently ulcerates and may invade underlying tissues.

The pigmented subtype is morphologically similar to the nodular ulcerative, although there are superficial and sclerodermiform variations. It should 
TABLE 1: Frequency of the clinical forms of basal cell carcinoma (BCC) adapted from different studies

\begin{tabular}{|c|c|c|c|c|c|}
\hline Author & Bernard $^{92}$ & Lascano $^{90}$ & Mantese $^{27}$ & Sobral Filho $^{91}$ & Minelli $^{93}$ \\
\hline Year/Country & 2008/France & 2005/Argentina & 2006/Brazil & 1995/Brazil & 1987/Brazil \\
\hline $\mathbf{N}$ & 1655 & 98 & 447 & 700 & 1663 \\
\hline Nodular / Ulcerated & $38.4 \%$ & $66.3 \%$ & $66.5 \%$ & $86.9 \%$ & $75.9 \%$ \\
\hline Superficial & $50.7 \%$ & $29.6 \%$ & $7.4 \%$ & $0.6 \%$ & $1.9 \%$ \\
\hline Sclerosing & $8.3 \%$ & $3.1 \%$ & $12.5 \%$ & $6.8 \%$ & $8.8 \%$ \\
\hline Pigmented & NC & NC & $13.6 \%$ & $5.7 \%$ & $12.2 \%$ \\
\hline Others & $2.6 \%$ & $1.0 \%$ & NC & NC & $1.2 \%$ \\
\hline
\end{tabular}

be differentiated from melanoma and pigmented seborrheic keratosis. It is the most commonly found variant in melanoderma patients. Due to contrast with the surrounding tissue, lower rates of positive margins are referred in this group. ${ }^{94.95}$

The sclerodermiform type has a worse prognosis, with greater chance of recurrence and infiltration. It mainly affects the face as a depressed plaque with ill-defined borders, which can rarely ulcerate. Due to the monotony of the symptoms and clinical presentation, diagnosis may be delayed, causing higher surgical morbidity.

Superficial tumors are located mainly on the trunk and shoulders and may be multiple. ${ }^{23.27}$ They are characterized as erythematous-scaly plaques with little infiltration and of slow growth. Differential diagnosis should be done with Bowen's disease, Paget's disease, psoriasis , eczema and dermatophytosis.

Fibroepithelioma is a rare form of BCC, preferably located in the lumbosacral, pubic or genitocrural region. It begins as papules or erythematous plaques that may become pedunculated. Due to the atypical clinical manifestation and rarity of the disease, the diagnosis is often not clinically suspected, and is only revealed in histopathology.

\section{HISTOPATHOLOGICAL CLASSIFICATION}

BCC is a malignant epithelial neoplasm of basaloid cells with large nuclei in relation to the cytoplasm and with loss of intercellular bridges, but with rare mitotic figures. The most suggestive characteristic for the diagnosis of BCC is the presence of clusters of cells peripherally arranged in palisade, usually with a gap between the stroma and tumor parenchyma.
There is diversity among the classifications of histopathological subtypes adopted by different authors. ${ }^{4,27,96-99}$ The frequencies of histological types adapted to a reductionist classification described in different studies are shown in Table $2 .{ }^{100-101}$

The macronodular form is the most common. It shows nodular masses of basaloid cells separated from the dermis by a typical artifact of separation. They eventually express adnexal, adenoid or cystic differentiation. Pigmented tumors follow the same structure; however, they produce melanin. Occasionally, central necrosis or cystic changes are seen within the tumor lobules. There are micronodular forms, where tumor blocks are smaller, with fewer than 15 cells in diameter, and more uniform than the macronodular type.

The superficial type is characterized by budding and irregular proliferation of basaloid cells forming peripheral palisade fixed to the bottom surface of the skin, usually atrophic. Fibroblasts surround the tumor cells and there is chronic inflammatory infiltrate in the upper dermis. They may have a multifocal aspect, with discontinuous epithelial tumor budding, intermingled with unaffected epidermis, complicating the assessment of margins in surgical specimens.

In fibroepithelioma of Pinkus, the tumor is histologically constituted by long, thin branching strands of BCC, some connected to the epidermis, anastomosing in fibrovascular stroma.

The sclerodermiform variant is composed of numerous tumor islands, usually infiltrating the reticular dermis and promoting an intense fibromatous reaction. The infiltrative variant is constituted by small and irregular basaloid cell islands invading the dermis, similar to what occurs in the sclerodermiform variant, but with smaller cell clusters. 
TABLE 2: Frequency of histopathological types of basal cell carcinoma adapted from different studies

\begin{tabular}{|c|c|c|c|c|c|c|c|}
\hline Author & Mantese $^{27}$ & Nasser $^{97}$ & Bandeira $^{98}$ & Betti $^{100}$ & Scrivener $^{22}$ & Gon $^{101}$ & Pelluchi $^{23}$ \\
\hline Year/Country & 2006/Brazil & 2005/Brazil & 2003/Brazil & 1995/Italy & 2002/France & 2008/Brazil & 2007/Italy \\
\hline $\mathbf{N}$ & 447 & 5254 & 704 & 693 & 13457 & 127 & 528 \\
\hline $\begin{array}{l}\text { Solid/ } \\
\text { Pigmented/ } \\
\text { Adenoid }\end{array}$ & $46.4 \%$ & $44.7 \%$ & $80.3 \%$ & $64.8 \%$ & $78.7 \%$ & $61.4 \%$ & $55.2 \%$ \\
\hline $\begin{array}{l}\text { Infiltrative / } \\
\text { Sclerosing }\end{array}$ & $8.7 \%$ & $10.0 \%$ & $4.8 \%$ & $16.6 \%$ & $15.1 \%$ & $8.7 \%$ & $13.4 \%$ \\
\hline Superficial & $7.8 \%$ & $45.3 \%$ & 14.1\% & $17.5 \%$ & $6.2 \%$ & $22.8 \%$ & $31.4 \%$ \\
\hline Mixed & $37.1 \%$ & NC & NC & NC & NC & NC & NC \\
\hline
\end{tabular}

NC: Unclassified

Metatypical BCC (basosquamous) is a skin tumor that shares characteristics of BCC and SCC, with particular behavior and histological features. Although morphologically similar to BCC, basosquamous BCC is more aggressive and metastasizes more frequently $(>7.4 \%)$. ${ }^{102}$ Some authors have questioned the existence of this subtype as an independent entity, since it can be difficult to differentiate it from collision tumors in which other cancers, such as SCC, appear side by side with a typical BCC in the same surgical specimen. ${ }^{9}$

In most cases $(37-43 \%)$, there is an association of histological types in the same tumor; however, there is clear predominance of one. ${ }^{3,27,103}$

The sclerodermiform, infiltrative and micronodular variants are considered to have infiltrative growth, with more aggressive clinical behavior and increased risk of recurrence. The macronodular, superficial, pigmented, and cystic variants are considered expansive, with a milder behavior. BCCs with multifocal characteristics tend to recur if the excision margin is small. ${ }^{9.99}$

\section{PRIMARY LOCATION}

BCC mostly occurs on sun exposed areas of the skin. In approximately $80 \%$ of the cases it is located on the face (30\% in the nasal area) and neck, although it has been described in the genital and areolar areas, groin, axillae, umbilicus, scalp, interdigital area and mucous membranes. ${ }^{9,41,104-111}$

Involvement of the trunk occurs in $15-43 \%$ of cases. $1,27,112$ The frequencies of topographies of involvement of BCC described by case studies are shown in Table 3. ${ }^{113}$

The occurrence of BCC in areas less exposed to the sun, about $20 \%$ of cases, and the rare involvement of other typically exposed areas, such as the backs of hands, indicate that other factors play a role in its genesis. ${ }^{4.114}$ Neoplasms that affect photoprotected and intertriginous areas are usually larger in diameter due to delayed diagnosis and may lead to worst prognosis, surgical morbidity and metastasis. 104,106,108,109

\section{GENETICS}

The development of BCC results from the interaction between various genes and environmental factors. Mutations in the PTCH gene (patched hedgehog), a tumor suppressor located in the 9q22 (PTCH1) and 1p32 (PTCH2) loci were associated with the appearance of $\mathrm{BCC}$ in $30 \%$ to $75 \%$ of sporadic cases and almost with all cases associated with basal cell nevus syndrome. ${ }^{12.26}$ Patched receptor is a receptor for ligands of the hedgehog protein family (HH) and is present in the plasma membrane of cells. Binding of $\mathrm{HH}$ to $\mathrm{PTCH}$ induces the release and activation of another protein located in the membrane - smoothened - expressed by the SMO gene. Activation of smoothened activates Gli-1 factor, which induces the transcription of several oncogenes involved in the development of BCC and other malignancies. PTCH gene mutations stimulate the hedgehog pathway due to the inability of the mutated patched protein to suppress smoothened (Figure 1). Mutations in the SMO gene are present in $10-21 \%$ of sporadic BCCs and mutations in the p53 gene are present in more than $50 \%$ of cases, although the p53 gene is more related to the progression than the origin of BCC. ${ }^{4,12,24}$

Animal models were developed from transgenic mice that express the smoothened protein in tissues. These animals have, in addition to multiple BCCs, numerous bone abnormalities, simulating basal cell nevus syndrome. ${ }^{115.116}$

Extragenic DNA also plays a role in tumor 
TABLE 3: Frequency of the sites of the body affected by basal cell carcinoma, adapted from different studies

\begin{tabular}{llllllllll}
\hline Author & Bernard $^{92}$ & Sobral Filho & Machado Filho & Lascano $^{90}$ & Mantese $^{27}$ & Gon $^{101}$ & Minelli $^{93}$ & Golcman $^{113}$ & Nasser $^{97}$ \\
\hline $\begin{array}{l}\text { Year/ } \\
\text { Country }\end{array}$ & $\begin{array}{l}\mathbf{2 0 0 8 /} \\
\text { France }\end{array}$ & $\begin{array}{l}\mathbf{1 9 9 5 /} \\
\text { Brazil }\end{array}$ & $\begin{array}{l}\mathbf{1 9 9 6 /} \\
\text { Brazil }\end{array}$ & $\begin{array}{l}\text { 2005/ } \\
\text { Argentina }\end{array}$ & $\begin{array}{l}\mathbf{2 0 0 6 /} \\
\text { Brazil }\end{array}$ & $\begin{array}{l}\text { 2008/ } \\
\text { Brazil }\end{array}$ & $\begin{array}{l}\text { 1987/ } \\
\text { Brazil }\end{array}$ & $\begin{array}{l}\text { 1978/ } \\
\text { Brazil }\end{array}$ & $\begin{array}{l}\text { 2005/ } \\
\text { Brazil }\end{array}$ \\
N & 1655 & 700 & 447 & 98 & 447 & 127 & 1663 & 412 & 1351 \\
\hline $\begin{array}{l}\text { Head and } \\
\text { neck }\end{array}$ & $64.5 \%$ & $81.7 \%$ & $78.3 \%$ & $55.1 \%$ & $80.6 \%$ & $70.1 \%$ & $95.9 \%$ & $80.0 \%$ & $78.8 \%$ \\
Trunk & $25.1 \%$ & $8.0 \%$ & $13.4 \%$ & $29.6 \%$ & $11.8 \%$ & $22.8 \%$ & $2.3 \%$ & $8.0 \%$ & $12.5 \%$ \\
Limbs & $10.4 \%$ & $10.3 \%$ & $8.3 \%$ & $15.3 \%$ & $7.6 \%$ & $7.1 \%$ & $1.8 \%$ & $3.5 \%$ & $8.7 \%$ \\
\hline
\end{tabular}

development. Microsatellites, which are short repetitive sequences of one to six nucleotides located throughout the genome, are important. The DNA of tumor cells usually shows changes in the number of repeated units in one or more microsatellites, and this is called microsatellite instability; the complete loss of a microsatellite is known as loss of heterozygosity. Changes in 12 of 18 microsatellites have been detected in BCCs; two of them are close to the TP53 and $\mathrm{MSH} 2$ suppressor genes. Many changes also occur near the PTCH gene. In $60 \%$ of familial and sporadic BCCs, alterations in the microsatellite D6S251 in the 6q14 region are described. All BCCs with some instability showed high histological risk (46\%). ${ }^{26.117}$

Other changes were identified in patients with
BCC based on genome sequencing studies. Mutations in pigment genes, such as melanocortin 1 receptor (MC1-R), are associated with susceptibility to melanoma and BCC. ${ }^{118.119}$ Nucleotide polymorphism in the loci 9p21, 7q32 (res157935 [T]), rs11170164 and in genes associated with DNA repair - XPD, XRCC XRCC 1 and 3 - were more prevalent in groups with BCC than controls. 41.120 However, gene variants that encode proteins involved in immune response, such as CTLA4 and XRCC3, reduce the risk of BCC; ${ }^{77,121,122}$ expression of HLA-DR4, as well as expression of the TNF allele haplotype a2b4d5, was associated with multiple lesions. ${ }^{2}$

Specifically, involvement of the trunk and development of multiple BCCs were related to genetic polymorphisms in glutathione S-transferase, NADPH

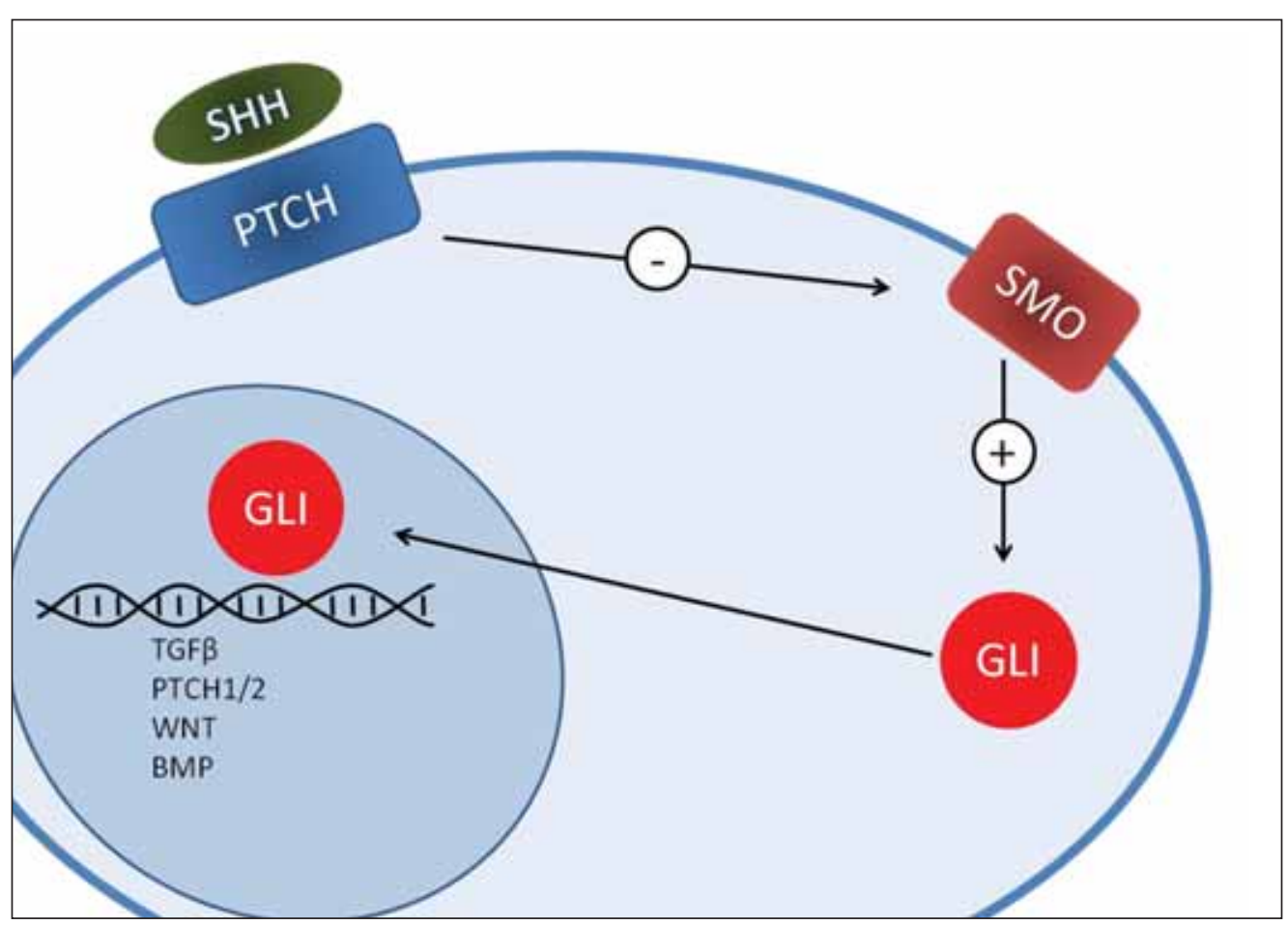

FIGURE 1: Representation of the hedgehog pathway SHH: sonic bedgebog protein, PTCH: Protein Patched bedgehog receptor, SMO, Smoothened receptor, GLI: GLI Factor-1, TGF,: Transforming growth factor type, WNT: wingless signaling pathway, BMP: bone morphogenetic protein 
and cytochrome P-450. ${ }^{3,41,123}$ In addition, trisomy of chromosome 6 was linked to increased aggressiveness of BCC. ${ }^{124}$

Mutations in the CDKN2A locus, which encodes the proteins p16 and p14 ${ }^{\mathrm{ARF}}$, were also detected in sporadic BCCs; however, mutations of oncogenes (ras) were found in an even less evident proportion $(0-30 \%)$, suggesting that the oncogenesis of BCC depends primarily on the failure of tumor suppression. In addition, numerous other gene polymorphisms have been studied in families of BCCs without significant risk association. ${ }^{26,120,125}$ Changes in apoptosis pathways, such as increased expression of BCL2, apoptotic pathway gene, TGF-,, MAPK (mitogen -activate protein kinase), calcium channels, Wnt/ , catenin and cell cycles also contribute to the oncogenetics of $\mathrm{BCC}$, but they are beyond the scope of this text. ${ }^{12.26}$

UV rays can lead to a degree of immunosuppression by depletion of dendritic cells and altered expression of cytokines that result in the diversion of cellular immune response to Th2 cells, inhibiting the ability of antigen presenting cells to induce antitumor activity, which may be relevant in tumor progression. ${ }^{1,24,25}$

Some cancers express the enzyme COX-2 as an antiapoptotic mechanism. ${ }^{126}$ Inhibition of this enzyme led to a $30 \%$ reduction in the incidence of new lesions in patients with basal cell nevus syndrome. ${ }^{127}$ However, the use of non-steroidal anti-inflammatory drugs did not provide significant protection against the recurrence of sporadic BCCs. ${ }^{128}$

Similarly to SCC, HPV viral particles were identified in $36 \%$ of BCCs, and only involvement of the superficial layers of the tumor was described; however, its pathogenetic role is not clear. ${ }^{129}$ Moreover, the presence of HPV serology was similar for cases with BCCs and controls. ${ }^{130}$

Patterns of gene expression that lead to phenotypic diversity of clinical presentations, histopathological subtypes and biologic behavior of BCCs have not yet been elucidated. ${ }^{40}$

Some genetic syndromes are associated with risk of BCCs, which should be suspected when there are multiple tumors or incidence at a young age.

Basal cell nevus syndrome (Gorlin-Goltz syndrome) is autosomal dominant and results from mutations in the PTCH gene. It is clinically characterized by multiple BCCs, especially on the face, but also in less exposed areas such as trunk and axillae, milium, epidermoid cysts, hyperkeratotic, depressed and punctate lesions in the palmoplantar regions (pits), bone deformities, especially mandibular cysts, which can lead to tooth loss, spina bifida, kyphoscoliosis and deformities in the ribs, with frequent calcification of cerebral falx observed in X-ray examination. There are usually changes in body proportions, with a disproportionate head to body and elongated limbs. There may be hypertelorism, prognathism, frontal bossing, syndactyly, cataracts, and other tumors such as ameloblastomas, cerebellar medulloblastomas, cardiac fibromas and fibrosarcomas. The presence of numerous ${ }^{131.132}$ acrochodons in children may be a marker of the syndrome. ${ }^{1.9}$

Bazex syndrome is an X-linked (Xq24-q27) dominant disorder characterized by multiple BCCs associated with follicular atrophodermias mainly located in the back of hands and feet, elbows and face, milia, facial anhidrosis and widespread hypotrichosis. 133.134

In linear and unilateral basal cell nevus syndrome, patients present with papules and nodules linear and unilaterally distributed, characterizing BCC, permeated by comedones and striae. ${ }^{135.136}$

In Rombo syndrome there is atrophodermia vermiculata, milia, hypotrichosis, trichoepitheliomas and peripheral vasodilation, telangiectasia, as well as risk of BCC development. Rasmussen's syndrome and cutaneous albinism are characterized by lack of melanin in the eyes, skin and hair and are associated with increased risk of malignant neoplasms. ${ }^{4.137-139}$

In xeroderma pigmentosum, there is a deficit in DNA defect repair that increases the risk of malignant skin cancer by more than 1000 times. ${ }^{140}$ Clinically, skin lesions usually begin early in life in sun exposed areas.There may be diffuse hyperpigmentation, lesions similar to ephelides, scaling and erythema with telangiectasias. Later, keratoses and malignant tumors such as SCC, BCC, and melanoma develop, and less frequently, sarcomas, fibromas, angiomas, histiocytomas, tumors in the tongue and gums. Patients present with photophobia, conjunctivitis, keratitis, corneal opacities and ectropion; there is higher frequency of malignant tumors in the lung, kidney, breast, uterus, gastrointestinal tract, pancreas, testicles and central nervous system. As for neurological abnormalities, patients may have mental retardation, abnormal reflexes, nerve deafness, microcephaly, ataxia, spasticity, choreoathetosis, sexual underdevelopment and dwarfism. ${ }^{141.142}$

The prevalence of BCCs developed from sebaceous nevi ranges from $2.0 \%$ to $6.5 \% .{ }^{30}$ When all adnexal tumors with potential origin in sebaceous nevi are considered, they occur in $30-50 \%$ of cases, typically after puberty . ${ }^{143.144}$

Other unusual syndromes associated with increased incidence of BCC are familial cylindromatosis, familial multiple trichoepithelioma, multiple infundibulocystic BCC, basaloid follicular 
hamartoma, Brooke-Spiegler, Muir-Torre, Cowden and Banayan Riley-Ruvalcaba. ${ }^{145-151}$

\section{PROGNOSIS}

The prognosis of BCC appears to have improved in recent decades in all countries, probably due to earlier diagnosis, leading to surgical interventions that result in less sequelae, greater access to health services and possible public awareness raised by educational campaigns. ${ }^{9}$

BCC usually behaves kinetically as a benign tumor, shows slow growth and takes more than six months to reach one centimeter. ${ }^{9.152}$ The average duration of lesions from the onset to diagnosis was 37.1 months for both genders. ${ }^{27}$

Cure rates exceed $90 \%$ with surgical excision, and specific mortality by BCC is inferior to $0.1 \%$. There are other effective therapeutic choices, but they go beyond the scope of this text. ${ }^{6.9}$

There are cases where infiltrative behavior affects all adjacent tissues, causing significant local morbidity, disfigurement, and mutilating surgery. The risk of recurrence increases if the tumor has more than two centimeters in diameter (stage II). This shows the importance of early diagnosis.

The staging of non-melanoma skin cancer depends on the largest diameter of the lesion, the involvement of adjacent tissues and systemic dissemination. Stage $\mathrm{I}$ is characterized by lesions smaller than two centimeters and disease limited to skin; stage II is represented by lesions larger than two centimeters, but the disease is still confined to the skin and subcutaneous tissue; stage III occurs by the invasion of underlying tissues, such as muscle, cartilage and bone, or lymphatic spread, and stage IV occurs by disease dissemination to other distant organs such as lungs and bones.

Recurrences can occur due to tumor remnants resulting from therapy. It was demonstrated that surgical excision without microscopic control of margins had a recurrence rate ranging between 3.1 and $6.8 \%$ in five years. The latent period between surgery and onset of recurrence varies, on average, from two months to two years; however, it occurs more frequently in the first six months, but there are reports of more than five years. ${ }^{153-157}$

Surgical excisions with positive margins recur in $15 \%$ to $67 \%$ of cases; however, they may occur after the report of histopathologically free margins (1.3 to $4.0 \%$ ). This occurs more commonly in multifocal superficial and sclerodermiform tumors. 153,156,158-163 These factors stress the need for the oncologic treatment of all patients. Nonetheless, the immediate systematic reevaluation of all BCCs with positive margins is not consensual.
The regions of embryonic fissures retroauricular perinasal, periorbital, peripalpebral and scalp are considered at higher risk for recurrence. ${ }^{162-164}$

The recurrent tumor has a worse prognosis because the relationship between the tumor and its stroma may be altered as a result of treatment primarily established, facilitating its dissemination. It may show exulcerations, ${ }^{154}$ more evident cellular dysplasia, loosening of the tumor cell cords, stromal fibrosis and reduction of peritumoral inflammatory reaction, increasing the spread of cancer cells. ${ }^{4.9}$

The incidence of metastasis of BCC is rare and ranges from $0.0028 \%$ to $0.55 \%$; less than 400 cases have been reported in the literature. ${ }^{4,165,166}$

The dependence of the BCC on its stroma may be a factor associated with reduced metastatic dissemination. The most frequent site of involvement is the regional lymph node in $68 \%$ of cases. Hematogenous dissemination may also occur affecting the lungs and pleura, liver and bones. Some authors claim that BCC only metastasizes when it is a mixed or metatypical tumor, while others associate this complication to previous radiotherapy of the tumor or lesions that have relapsed multiple times, usually over $5-10 \mathrm{~cm}$ and evolution over five years. Recurrent and invasive BCCs are little responsive to chemotherapy and five-year survival rate is only $10 \%{ }^{1,165}$

\section{FINAL CONSIDERATIONS}

The prevention of BCC is based on knowledge of risk factors, early diagnosis and adoption of preventive measures, especially in susceptible populations.

Due to evidence of involvement of UV rays on BCC development, educational measures on intense and unprotected sun exposure should be encouraged, such as information about times of lower incidence of UVB, occupational and leisure protection, prevention of sunburn, use of appropriate clothing, hats, protective films for cars and use of a broad-spectrum sunscreen.

There is controversy regarding the protective action of sunscreens alone. Some authors suggest that their use would encourage risky behavior in which the individual would expose himself more to the sun, believing to be fully protected. ${ }^{34.167}$ Failure to reduce the incidence of BCC, despite the prolonged use of sunscreens, has also been shown. ${ }^{1.168-170}$

One possible explanation for this is that the studies were based on sunscreens with low UVA protection, use for less than ten years, effectiveness of application, frequency and reapplication of the product, thus reducing their function. ${ }^{167-174}$ However, other studies suggest that regular use of sunscreens in 
the first 18 years of life may decrease the risk of these tumors by $78 \% .{ }^{8}$ A lower risk of multiple tumors was observed in the groups who used them for prolonged periods. ${ }^{77.168}$ Still, one can notice a tendency to protective effect based on the frequency of use of sunscreens, but these results were not statistically significant. ${ }^{16,168,175}$

Frequent use of sunscreens and sun protection measures are recommended to reduce costs to the health system due to actinic dermatoses, especially actinic keratoses and SCC. In this study, with a five-year follow up, there was a $10 \%$ reduction in the incidence of BCC, although not statistically significant. ${ }^{175}$

Drugs such as isotretinoin, acitretin and beta carotene did not show benefits in preventing BCC in the general population, although retinoids are indicated to treat Gorlin syndrome, with a $26 \%$ regression rate and reduction of up to $40 \%$ of new BCCs. ${ }^{176-180}$

Another point of concern related to skin carcinogenesis is the demand for artificial tanning beds, especially by young women, who use these services three or four times more often than men. ${ }^{42}$ The emission spectrum of UV rays in tanning booths resembles that of the solar spectrum in terms of UVB, but it may be 10 to 15 times higher for UVA. ${ }^{181}$ The tanning industry makes billions of dollars annually, and there is a growing demand for the service, which requires solid evidence for prohibition or recommendation. ${ }^{182}$ In 1988, only $1 \%$ of adult Americans reported using artificial tanning beds, whereas in 2007 this percentage rose to $27 \% .{ }^{183}$

The literature presents conflicting results. A possible limitation would be confounding factors such as natural sunlight exposure, since individuals who seek artificial tanning also expose themselves to the sun for the same purpose, as well as the long latency period between exposure and onset of cancer. ${ }^{66.184}$ Some studies did not find evidence of risk of nonmelanoma tumors, ${ }^{185}$ whereas others have associated the habit of artificial tanning with BCC $(\mathrm{OR}=1.5)$ and SCC $(\mathrm{OR}=2.5)$, even when adjusted for sunburns , sunbathing and sun exposure. ${ }^{43.186-188}$ There is also a strong association with melanoma, even though a relationship between dose and response is not quantified. ${ }^{101,184,189,190}$

One of the supposed benefits of tanning beds would be the production of vitamin $\mathrm{D}$; however, oral intake of this vitamin is more efficient and accessible to the population. ${ }^{188}$ Another misconception is that artificial tanning would provide protection against subsequent sun exposure, but this protection corresponds to an FPS 2 or 3, something easily achievable by use of sunscreens. ${ }^{182}$

The World Health Organization warned about the dangers of artificial tanning and warned that children under 18 years old should not undergo this procedure. ${ }^{191}$

The education of patients regarding risk factors, attention to the diagnosis of minor lesions by selfexamination, as well as participation in prevention campaigns are essential in prevention and improved prognosis.

Campaigns to prevent skin cancer have a potential impact on early diagnosis and education of the population. In 1990, more than 100,000 people were examined and about 10,000 skin cancers, detected in the US. However, due to the high cost of examining the general population, the follow-up of risk groups may be a more optimal strategy in prevention. ${ }^{8.34}$

The Brazilian Society of Dermatology has held annually since 1999 the national skin cancer prevention campaign, screening on a single day more than 30,000 people across the country, with detection rates of up to $10 \%$. BCC affects between $6 \%$ and $7 \%$ of those examined. There is intense dissemination of information in the media. ${ }^{192}$

The high frequency of $\mathrm{BCC}$ and the progressive increase in its incidence make it an environmental and occupational disease, with a clear impact on the patients' quality of life. This causes a significant burden to the health system, especially in cases of invasive behavior and relapse after treatment. ${ }^{193.194}$

The study of the epidemiology of BCC allows the identification of behavioral and phenotypical elements for the establishment of risk groups. This leads to the development of sanitary measures for primary prevention in the population; it also improves screening campaigns, encourages the promotion of educational programs in schools and communities, optimizes actions in public and occupational health, and reduces morbidity and health system expenditures by early recognition and treatment of lesions. 


\section{REFERENCES}

1. Lear JT, Harvey I, de Berker D, Strange RC, Fryer AA. Basal cell carcinoma. J R Soc Med. 1998;91:585-8.

2. Maia M, Proenca NG, de Moraes JC. Risk factors for basal cell carcinoma: a case-control study. Rev Saude Publica. 1995;29:27-37.

3. Rubin Al, Chen EH, Ratner D. Basal-cell carcinoma. N Engl J Med. 2005;353:2262-9.

4. Roewert-Huber J, Lange-Asschenfeldt B, Stockfleth E, Kerl H. Epidemiology and aetiology of basal cell carcinoma. Br J Dermatol. 2007;157(Suppl 2):47-51.

5. Wetzig T, Maschke J, Kendler M, Simon JC. Treatment of basal cell carcinoma. J Dtsch Dermatol Ges. 2009 [Epub ahead of print].

6. Skelton LA. The effective treatment of basal cell carcinoma. Br J Nurs. 2009;18:346; 348-50.

7. Abulafia J. Epiteliomas cutâneos: ensayo de classificación histogenética. An Bras Dermatol. 1963:38:14-31.

8. Gloster HM Jr., Brodland DG. The epidemiology of skin cancer. Dermatol Surg. 1996;22:217-26.

9. Kopke LFF Schmidt SM. Carcinoma basocelular. An Bras Dermatol. 2002:77:249-82.

10. Rocha FP, Menezes AMB, Almeida Jr. HL, Tomasi E. Marcadores e fatores de risco para queratoses actínicas e carcinomas basocelulares: um estudo de casocontrole. An Bras Dermatol. 2004:79:441-54.

11. Youssef KK, Van Keymeulen A, Lapouge G, Beck B, Michaux C, Achouri Y, et al. Identification of the cell lineage at the origin of basal cell carcinoma. Nat Cell Biol. 2010;12:299-305.

12. Donovan J. Review of the hair follicle origin hypothesis for basal cell carcinoma. Dermatol Surg. 2009;35:1311-23.

13. Betti R, Facchetti M, Menni S, Crosti C. Basal cell carcinoma of the sole. J Dermatol. 2005;32:450-3

14. Orsini RC, Catanzariti A, Saltrick K, Mendicino RW, Stokar L. Basal cell carcinoma of the nail unit: a case report. Foot Ankle Int. 2001;22:675-8.

15. Armstrong BK, Kricker A. How much melanoma is caused by sun exposure? Melanoma Res. 1993;3:395-401.

16. Kyrgidis A, Tzellos TG, Vahtsevanos K, Triaridis S. New Concepts for Basal Cell Carcinoma. Demographic, Clinical, Histological Risk Factors, and Biomarkers. A Systematic Review of Evidence Regarding Risk for Tumor Development, Susceptibility for Second Primary and Recurrence. J Surg Res. 2010;159:545-56.

17. Gallagher RP, Hill GB, Bajdik CD, Fincham S, Coldman AJ, McLean DI, et al. Sunlight exposure, pigmentary factors, and risk of nonmelanocytic skin cancer. I. Basal cell carcinoma. Arch Dermatol.1995;131:157-63.

18. Kricker A, Armstrong BK, English DR, Heenan PJ. Pigmentary and cutaneous risk factors for non-melanocytic skin cancer--a case-control study. Int J Cancer. 1991;48:650-62.

19. Armstrong BK, Kricker A. The epidemiology of UV induced skin cancer. J Photochem Photobiol. B 2001;63:8-18.

20. Han J, Colditz GA, Hunter DJ. Risk factors for skin cancers: a nested case-control study within the Nurses' Health Study. Int J Epidemiol. 2006;35:1514-21.

21. Zanetti R, Rosso S, Martinez C, Nieto A, Miranda A, Mercier M, et al. Comparison of risk patterns in carcinoma and melanoma of the skin in men: a multi-centre case-case-control study. Br J Cancer. 2006;94:743-51.

22. Scrivener $Y$, Grosshans $E$, Cribier B. Variations of basal cell carcinomas according to gender, age, location and histopathological subtype. $\mathrm{Br} J$ Dermatol. 2002;147:41-7.

23. Pelucchi C, Di Landro A, Naldi L, La Vecchia C; Oncology Study Group of the Italian Group for Epidemiologic Research in Dermatology (GISED). Risk factors for histological types and anatomic sites of cutaneous basal-cell carcinoma: an italian case-control study. J Invest Dermatol. 2007;127:935-44.

24. Madan V, Hoban P, Strange RC, Fryer AA, Lear JT. Genetics and risk factors for basal cell carcinoma. Br J Dermatol. 2006;154 Suppl 1:5-7.

25. Welsh MM, Karagas MR, Applebaum KM, Spencer SK, Perry AE, Nelson HH. A role for ultraviolet radiation immunosuppression in non-melanoma skin cancer as evidenced by gene-environment interactions. Carcinogenesis. 2008;29:1950-4.

26. Greinert R. Skin cancer: new markers for better prevention. Pathobiology. 2009;76: 64-81.

27. Mantese SAO, Berbert ALCV, Gomides MDA, Rocha A. Carcinoma basocelular Análise de 300 casos observados em Uberlândia - MG. An Bras Dermatol. 2006; 81:136-42.

28. Brasil. Ministério da Saúde. Secretaria de Atenção à Saúde. Instituto Nacional de Câncer. Coordenação de Prevenção e Vigilância de Câncer. Estimativas 2010: Incidência de Câncer no Brasil. Rio de Janeiro: INCA; 2009. 98 p.

29. Sociedade Brasileira de Dermatologia. Perfil nosológico das consultas dermatológicas no Brasil. An Bras Dermatol. 2006:81:549-58.

30. Lear W, Dahlke E, Murray CA. Basal cell carcinoma: review of epidemiology, pathogenesis, and associated risk factors. J Cutan Med Surg. 2007;11:19-30.

31. Geller AC, Annas GD. Epidemiology of melanoma and nonmelanoma skin cancer.
Semin Oncol Nurs. 2003;19:2-11

32. Leiter U, Garbe C. Epidemiology of melanoma and nonmelanoma skin cancer-the role of sunlight. Adv Exp Med Biol. 2008;624:89-103.

33. Katalinic A, Kunze $U$, Schafer T. Epidemiology of cutaneous melanoma and non-melanoma skin cancer in Schleswig-Holstein, Germany: incidence, clinical subtypes, tumour stages and localization (epidemiology of skin cancer). Br J Dermatol. 2003;149: 1200-6.

34. Okida F, Pouza CET, Madalosso G, Pouza CET, Scaff A, Romiti N. Estudo da prevalência de casos de câncer da pele e análise da eficácia da proteção solar na prevenção de lesões causadas por radiação ultravioleta em uma amostra da população. An Bras Dermatol. 2001;77:403-12.

35. Machado Filho CDAS, Fagundes DS, Sender F, Paschoal LHC, Costa MCC Carazzato SG, et al. Neoplasias malignas cutâneas: estudo epidemiológico. An Bras Dermatol. 1996:71:479-84.

36. Bulliard JL, Panizzon RG, Levi F. Epidemiology of epithelial skin cancers. Rev Med Suisse. 2009;5:882,4-8.

37. van Hattem S, Aarts MJ, Louwman WJ, Neumann HA, Coebergh JW, Looman CW, et al. Increase in basal cell carcinoma incidence steepest in individuals with high socioeconomic status: results of a cancer registry study in The Netherlands. Br J Dermatol. 2009;161:840-5.

38. Diepgen TL, Mahler V. The epidemiology of skin cancer. Br J Dermatol. 2002;146 Suppl 61:1-6.

39. Souza RJSP, Mattedi AP, Rezende ML, Corrêa MP, Duarte EM. Estimativa do custo do tratamento de câncer de pele tipo melanoma no Estado de São Paulo - Brasil. An Bras Dermatol. 2009:84:237-43.

40. Madan V, Lear JT, Szeimies RM. Non-melanoma skin cancer. Lancet. 2010;375:673-85

41. Hoban PR, Ramachandran S, Strange RC. Environment, phenotype and genetics: risk factors associated with BCC of the skin. Expert Rev Anticancer Ther. 2002;2:570-9.

42. Faurschou A, Wulf HC. Ecological analysis of the relation between sunbeds and skin cancer. Photodermatol Photoimmunol Photomed. 2007;23:120-5.

43. Karagas MR, Stannard VA, Mott LA, Slattery MJ, Spencer SK, Weinstock MA. Use of tanning devices and risk of basal cell and squamous cell skin cancers. J Natl Cancer Inst. 2002;94:224-6.

44. Lovatt TJ, Lear JT, Bastrilles J, Wong C, Griffiths CE, Samarasinghe V, et al. Associations between ultraviolet radiation, basal cell carcinoma site and histology, host characteristics, and rate of development of further tumors. J Am Acad Dermatol. 2005;52:468-73.

45. Ramos J, Villa J, Ruiz A, Armstrong R, Matta J. UV dose determines key charac teristics of nonmelanoma skin cancer. Cancer Epidemiol Biomarkers Prev. 2004;13:2006-11.

46. Efron PA, Chen MK, Glavin FL, Kays DW, Beierle EA. Pediatric basal cell carcinoma: case reports and literature review. J Pediatr Surg. 2008;43:2277-80.

47. Raasch BA, Buettner PG, Garbe C. Basal cell carcinoma: histological classification and body-site distribution. Br J Dermatol 2006;155:401-7.

48. Neale RE, Davis M, Pandeya N, Whiteman DC, Green AC. Basal cell carcinoma on the trunk is associated with excessive sun exposure. J Am Acad Dermatol. 2007:56:380-6.

49. Boyd AS, Shyr Y, King LE Jr. Basal cell carcinoma in young women: an evaluation of the association of tanning bed use and smoking. J Am Acad Dermatol. 2002;46:706-9.

50. Dinehart SM, Dodge R, Stanley WE, Franks HH, Pollack SV. Basal cell carcinoma treated with Mohs surgery: a comparison of 54 younger patients with 1050 older patients. J Dermatol Surg Oncol. 1992;18:560-6.

51. Saldanha G, Fletcher A, Slater DN. Basal cell carcinoma: a dermatopathological and molecular biological update. Br J Dermatol. 2003;148:195-202.

52. Sahl WJ, Glore S, Garrison P, Oakleaf K, Johnson SD. Basal cell carcinoma and lifestyle characteristics. Int J Dermatol. 1995;34:398-402.

53. Green A, Battistutta D. Incidence and determinants of skin cancer in a high-risk Australian population. Int J Cancer. 1990;46:356-61.

54. Vlajinac HD, Adanja BJ, Lazar ZF, Bogavac AN, Bjekiç MD, Marinkovic JM, et al. Risk factors for basal cell carcinoma. Acta Oncol. 2000;39:611-6.

55. Gohara MA. Skin cancer in skins of color. J Drugs Dermatol. 2008:7:441-5.

56. Jackson BA. Nonmelanoma skin cancer in persons of color. Semin Cutan Med Surg. 2009;28:93-5.

57. Feizy V, Toosi S. Relation of basal cell carcinoma to hair dye use. J Am Acad Dermatol. 2009;61:532-3.

58. Walther U, Kron M, Sander S, Sebastian G, Sander R, Peter RU, et al. Risk and protective factors for sporadic basal cell carcinoma: results of a two-centre casecontrol study in southern Germany. Clinical actinic elastosis may be a protective factor. $\mathrm{Br} J$ Dermatol 2004:151:170-8. 
59. Bariani RL, Nahas FX, Barbosa MV, Farah AB, Ferreira LM. Basal cell carcinoma: an updated epidemiological and therapeutically profile of an urban population. Acta Cir Bras. 2006;21:66-73.

60. Letzel S, Drexler H. Occupationally related tumors in tar refinery workers. J Am Acad Dermatol. 1998;39:712-20.

61. Corona R, Dogliotti E, D'Errico M, Sera F, lavarone I, Baliva G, et al. Risk factors for basal cell carcinoma in a Mediterranean population: role of recreational sun exposure early in life. Arch Dermatol. 2001;137:1162-8.

62. Lear JT, Tan BB, Smith AG, Bowers W, Jones PW, Heagerty AH, et al. Risk factors for basal cell carcinoma in the UK: case-control study in 806 patients. J R Soc Med. 1997;90:371-4.

63. van Dam RM, Huang Z, Rimm EB, Weinstock MA, Spiegelman D, Colditz GA, et al Risk factors for basal cell carcinoma of the skin in men: results from the health professionals follow-up study. Am J Epidemiol. 1999;150: 459-68.

64. Ruiz Lascano A, Kuznitzky R, Garay I, Ducasse C, Albertini R. Risk factors for basa cell carcinoma. Case-control study in Cordoba. Medicina (B Aires). 2005;65:495-500.

65. Karagas MR, Nelson HH, Zens MS, Linet M, Stukel TA, Spencer S, et al. Squamous cell and basal cell carcinoma of the skin in relation to radiation therapy and potential modification of risk by sun exposure. Epidemiology. 2007;18:776-84.

66. Abdulla FR, Feldman SR, Williford PM, Krowchuk D, Kaur M. Tanning and skin cancer. Pediatr Dermatol. 2005:22:501-12.

67. Karagas MR, Stukel TA, Umland V, Tsoukas MM, Mott LA, Sorensen HT, et al. Reported use of photosensitizing medications and basal cell and squamous cell carcinoma of the skin: results of a population-based case-control study. J Invest Dermatol. 2007:127:2901-3.

68. Cabrera HN, Gómez ML. Skin cancer induced by arsenic in the water. J Cutan Med Surg. 2003;7:106-11.

69. Ozyazgan I, Kontas 0. Previous injuries or scars as risk factors for the development of basal cell carcinoma. Scand J Plast Reconstr Surg Hand Surg. 2004;38:11-5.

70. Spiewak R. Pesticides as a cause of occupational skin diseases in farmers. Ann Agric Environ Med. 2001;8:1-5.

71. Kennedy C, Bajdik CD, Willemze R, Bouwes Bavinck JN. Chemical exposures other than arsenic are probably not important risk factors for squamous cell carcinoma, basal cell carcinoma and malignant melanoma of the skin. $\mathrm{Br} \mathrm{J}$ Dermatol. 2005:152:194-7.

72. Barthel E. Cancer risk in pesticide exposed agricultural workers. Arch Geschwulstforsch. 1981;55:481-8

73. Freedman DM, Sigurdson A, Doody MM, Mabuchi K, Linet MS. Risk of basal cell carcinoma in relation to alcohol intake and smoking. Cancer Epidemiol Biomarkers Prev. 2003;12:1540-3

74. Wojno TH. The association between cigarette smoking and basal cell carcinoma of the eyelids in women. Ophthal Plast Reconstr Surg. 1999;15:390-2.

75. De Hertog SA, Wensveen CA, Bastiaens MT, Kielich CJ, Berkhout MJ, Westendorp RG, et al. Relation between smoking and skin cancer. J Clin Oncol. 2001:19:231-8.

76. Ansems TM, van der Pols JC, Hughes MC, Ibiebele T, Marks GC, Green AC. Alcohol intake and risk of skin cancer: a prospective study. Eur J Clin Nutr. 2008;62:162-70.

77. Kyrgidis A, Tzellos TG, Vahtsevanos K, Triaridis S. New Concepts for Basal Cell Carcinoma. Demographic, Clinical, Histological Risk Factors, and Biomarkers. A Systematic Review of Evidence Regarding Risk for Tumor Development, Susceptibility for Second Primary and Recurrence. J Surg Res. 2010:159:545-56.

78. Fung TT, Hunter DJ, Spiegelman D, Colditz GA, Rimm EB, Willett WC. Intake of alcohol and alcoholic beverages and the risk of basal cell carcinoma of the skin. Cancer Epidemiol Biomarkers Prev. 2002;11:1119-22.

79. McNaughton SA, Marks GC, Green AC. Role of dietary factors in the development of basal cell cancer and squamous cell cancer of the skin. Cancer Epidemiol Biomarkers Prev. 2005;14:1596-607.

80. McNaughton SA, Marks GC, Gaffney P, Williams G, Green AC. Antioxidants and basal cell carcinoma of the skin: a nested case-control study. Cancer Causes Control. 2005:16:609-18.

81. Gandini S, Raimondi S, Gnagnarella P, Doré JF, Maisonneuve P, Testori A. Vitamin D and skin cancer: a meta-analysis. Eur J Cancer. 2009;45:634-41.

82. Asgari MM, Tang J, Epstein EH Jr, Chren MM, Warton EM, Quesenberry CP Jr, et al. Statin use and risk of basal cell carcinoma. J Am Acad Dermatol. 2009;61:66-72.

83. Asgari MM, Tang J, Warton ME, Chren MM, Quesenberry CP Jr, Bikle D, et al. Association of Prediagnostic Serum Vitamin D Levels with the Development of Basal Cell Carcinoma. J Invest Dermatol. 2010;130:1438-43.

84. Heffernan TP, Kawasumi M, Blasina A, Anderes K, Conney AH, Nghiem P. ATRChk1 pathway inhibition promotes apoptosis after UV treatment in primary human keratinocytes: potential basis for the UV protective effects of caffeine. J Invest Dermatol. 2009;129:1805-15.

85. Lu YP, Lou YR, Xie JG, Peng QY, Zhou S, Lin Y, et al. Caffeine and caffeine sodium benzoate have a sunscreen effect, enhance UVB-induced apoptosis, and inhibit UVB-induced skin carcinogenesis in SKH-1 mice. Carcinogenesis. 2007;28:199-206.
86. Abel EL, Hendrix SO, McNeeley SG, Johnson KC, Rosenberg CA, MossavarRahmani $Y$, et al. Daily coffee consumption and prevalence of nonmelanoma skin cancer in Caucasian women. Eur J Cancer Prev. 2007:16:446-52.

87. Tran H, Chen K, Shumack S. Epidemiology and aetiology of basal cell carcinoma Br J Dermatol. 2003;149 Suppl 66:50-2.

88. Richmond-Sinclair NM, Pandeya N, Williams GM, Neale RE, van der Pols JC, Green AC. Clinical signs of photodamage are associated with basal cell carcinoma multiplicity and site: A 16-year longitudinal study. Int J Cancer. 2010;127:2622-9.

89. Mseddi M, Marrekchi S, Abdelmaksoud W, Bouassida S, Meziou TJ, Boudaya S, et al. Epidemio-clinical profile of skin cancer in southern Tunisia. Tunis Med. 2007;85:505-8.

90. Lascano AR, Kuznitzky R, Garay I, Ducasse C, Albertini R. Factores de riesgo para carcinoma basocelular. Estudio de casos-controles en Cordoba. Medicina (B Aires). 2005;65:495-500.

91. Sobral Filho JF, Botelho G, Ramalho GL, Farias RL, Oliveira Júnior R. Variáveis epidemiológicas do carcinoma basocelular na Paraíba. CCS. 1995;14:38-45

92. Bernard P, Dupuy A, Sasco A, Brun P, Duru G, Nicoloyannis N, et al. Basal cell carcinomas and actinic keratoses seen in dermatological practice in France: a cross-sectional survey. Dermatology. 2008;216:194-9.

93. Minelli L. Estudo estatístico do carcinoma basocelular em Londrina, Paraná, Brasil. An Bras Dermatol. 1987;62:321-5.

94. Aoyagi S, Nouri K. Difference between pigmented and nonpigmented basal cell carcinoma treated with Mohs micrographic surgery. Dermatol Surg. 2006;32:1375-9.

95. Betti R, Gualandri L, Cerri A, Inselvini E, Crosti C. Clinical features and histologic pattern analysis of pigmented basal cell carcinomas in an Italian population. J Dermatol. 1998:25:691-4.

96. McGuire JF, Ge NN, Dyson S. Nonmelanoma skin cancer of the head and neck I: histopathology and clinical behavior. Am J Otolaryngol. 2009;30:121-33.

97. Nasser N. Epidemiologia dos carcinomas basocelulares em Blumenau, SC, Brasil, de 1980 a 1999. An Bras Dermatol. 2005;80:363-8.

98. Bandeira AM, Silva VB, Silva JF, Mazza E. Carcinoma basocelular: estudo clínico e anatomopatológico de 704 tumores. An Bras Dermatol. 2003:78:23-34.

99. Rippey JJ. Why classify basal cell carcinomas? Histopathology. 1998;32:393-8.

100. Betti R, Inselvini E, Carducci M, Crosti C. Age and site prevalence of histologic subtypes of basal cell carcinomas. Int J Dermatol. 1995;34:174-6.

101. Gon AS. Fatores de risco para o carcinoma basocelular: estudo de casos e controles. In: Curso de Pós-graduação em medicina e ciências da saúde da Universidade Estadual de Londrina., Vol. PhD. Londrina-PR: Universidade Estadual de Londrina - UEL. 2008; 76

102. Tarallo M, Cigna E, Frati R, Delfino S, Innocenzi D, Fama U, et al. Metatypical basa cell carcinoma: a clinical review. J Exp Clin Cancer Res. 2008;27:65.

103. Cohen PR, Schulze KE, Nelson BR. Basal cell carcinoma with mixed histology: a possible pathogenesis for recurrent skin cancer. Dermatol Surg. 2006:32:542-51.

104. Betti R, Bruscagin C, Inselvini E, Crosti C. Basal cell carcinomas of covered and unusual sites of the body. Int J Dermatol. 1997;36:503-5.

105. Avci 0, Pabuccuo Пlu U, Koçdor MA, Unlü M, Akin C, Soyal C, et al. Basal cell carcinoma of the nipple - an unusual location in a male patient. J Dtsch Dermatol Ges. 2008;6:130-2.

106. Bordel Gómez MT, Sánchez Estella J, Cardeñoso Alvarez E, Santos Durán JC Román Curto $\mathrm{C}$. Basocellular cancer of the vulva: a rare location for one of the most frequent types of skin cancer. Actas Dermosifiliogr. 2006;97:415-6.

107. Sarfati B, Lazar CC, Goubin I, Zwillinger N, Lorenceau B. Basal-cell carcinoma of fingers: A rare location not to be ignored. Ann Chir Plast Esthet. 2010;55:74-7.

108. Benamar L, Azzouzi S, Janati K, Benchikhi H, Lakhdar H. Axillary basal cell carcinoma: a rare localization. Ann Dermatol Venereol. 2005;132:191.

109. Redondo Martínez E, López AR, Cruz Benavides F, Camacho Galán R. Basal cell carcinoma of the scrotum. A rare localization linked to a bad prognosis. Arch Esp Urol. 2000:53:642-4

110. Pagliani G, Costa P, Papaleo M. Skin tumors. Localization of basal cell carcinoma in 162 patients. Minerva Chir. 1995;50:557-61.

111. Montagliani L, Aubert P, Vergeau B, Rivière P, Gaudry P, Dufau JP, et al. Perianal basal cell carcinoma. Presse Med. 2004;33:389-90

112. Lear JT, Smith AG, Strange RC, Fryer AA. Patients with truncal basal cell carcinoma represent a high-risk group. Arch Dermatol. 1998:134:373.

113. Golcman B, Friedhofer H, Rivitti EA, Anger M, Souza LC, Golcman R. Carcinomas basocelular e espinocelular da pele: estudo de sua incidência, tempo de evolução e seguimento pós-opertatório em 955 pacientes, por um período de 6 anos. An Bras Dermatol. 1978;53:373-83

114. van Zuuren EJ, Bastiaens MT, Posma AN, Bouwes Bavinck JN. Basal cell carcinoma on the dorsum of the hand: report of 11 cases. J Eur Acad Dermatol Venereol. 2000;14:307-10.

115. Oro AE, Higgins KM, Hu Z, Bonifas JM, Epstein EH Jr, Scott MP. Basal cell carcinomas in mice overexpressing sonic hedgehog. Science. 1997;276:817-21. 
116. Cobourne MT, Xavier GM, Depew M, Hagan L, Sealby J, Webster Z, et al. Sonic hedgehog signalling inhibits palatogenesis and arrests tooth development in a mouse model of the nevoid basal cell carcinoma syndrome. Dev Biol. 2009;331:38-49

117. Martinez MAR, Francisco G, Cabral LS, Ruiz IRG, Festa Neto C. Genética molecular aplicada ao câncer cutâneo não melanoma. An Bras Dermatol. 2006;81:405-19.

118. Gudbjartsson DF, Sulem P, Stacey SN, Goldstein AM, Rafnar T, Sigurgeirsson B, et al. ASIP and TYR pigmentation variants associate with cutaneous melanoma and basal cell carcinoma. Nat Genet. 2008;40:886-91.

119. Han J, Kraft P, Colditz GA, Wong J, Hunter DJ. Melanocortin 1 receptor variants and skin cancer risk. Int J Cancer. 2006;119:1976-84.

120. Stacey SN, Sulem P, Masson G, Gudjonsson SA, Thorleifsson G, Jakobsdottir M, et al. New common variants affecting susceptibility to basal cell carcinoma. Nat Genet. 2009;41:909-14.

121. Welsh MM, Applebaum KM, Spencer SK, Perry AE, Karagas MR, Nelson HH. CTLA4 variants, UV-induced tolerance, and risk of non-melanoma skin cancer. Cancer Res. 2009;69:6158-63.

122. Scherer D, Bermejo JL, Rudnai P, Gurzau E, Koppova K, Hemminki K, et al. MC1R variants associated susceptibility to basal cell carcinoma of skin: interaction with host factors and XRCC3 polymorphism. Int J Cancer. 2008;122:1787-93.

123. Lear JT, Smith AG, Bowers B, Heagearty AH, Jones PW, Gilford J, et al. Truncal tumor site is associated with high risk of multiple basal cell carcinoma and is influenced by glutathione S-transferase, GSTT1, and cytochrome P450, CYP1A1 genotypes, and their interaction. J Invest Dermatol. 1997;108:519-22.

124. Nangia R, Sait SN, Block AW, Zhang PJ. Trisomy 6 in basal cell carcinomas correlates with metastatic potential: a dual color fluorescence in situ hybridization study on paraffin sections. Cancer. 2001;91:1927-32.

125. Stacey SN, Gudbjartsson DF, Sulem P, Bergthorsson JT, Kumar R, Thorleifsson G, et al. Common variants on $1 \mathrm{p} 36$ and $1 \mathrm{q} 42$ are associated with cutaneous basal cell carcinoma but not with melanoma or pigmentation traits. Nat Genet. 2008;40:1313-8.

126. Mendes RA, Carvalho JF, Waal I. An overview on the expression of cyclooxygenase-2 in tumors of the head and neck. Oral Oncol 2009;45:e124-8.

127. Tang JY, Aszterbaum M, Athar M, Barsanti F, Cappola C, Estevez N, et al. Basal cell carcinoma chemoprevention with nonsteroidal anti-inflammatory drugs in genetically predisposed PTCH1+/- humans and mice. Cancer Prev Res (Phila Pa). 2010;3:25-34.

128. Grau MV, Baron JA, Langholz B, Karagas M, Greenberg ER, Stukel TA, et al. Effect of NSAIDs on the recurrence of nonmelanoma skin cancer. Int $\mathrm{J}$ Cancer. 2006;119:682-6.

129. Shamanin V, zur Hausen $\mathrm{H}$, Lavergne D, Proby CM, Leigh IM, Neumann C, et al. Human papillomavirus infections in nonmelanoma skin cancers from renal transplant recipients and nonimmunosuppressed patients. J Natl Cancer Inst. 1996;88:802-11.

130. Karagas MR, Nelson HH, Sehr P, Waterboer T, Stukel TA, Andrew A, et al. Human papillomavirus infection and incidence of squamous cell and basal cell carcinomas of the skin. J Natl Cancer Inst. 2006;98:389-95.

131. Acocella A, Sacco R, Bertolai R, Sacco N. Genetic and clinicopathologic aspects of Gorlin-Goltz syndrome (NBCCS): presentation of two case reports and literature review. Minerva Stomatol. 2009;58:43-53.

132. Lo Muzio L. Nevoid basal cell carcinoma syndrome (Gorlin syndrome). Orphanet J Rare Dis. 2008;3:32

133. Kidd A, Carson L, Gregory DW, de Silva D, Holmes J, Dean JC, et al. A Scottish family with Bazex-Dupre-Christol syndrome: follicular atrophoderma, congenital hypotrichosis, and basal cell carcinoma. J Med Genet. 1996;33:493-7.

134. Torrelo A, Sprecher E, Mediero IG, Bergman R, Zambrano A. What syndrome is this? Bazex-Dupre-Christol syndrome. Pediatr Dermatol. 2006;23:286-90.

135. Jih MH. Linear unilateral basal-cell nevus syndrome with comedones. Dermatol Online J. 2002;8:12

136. Kimyai-Asadi A, Jih MH. Linear basal cell nevus. South Med J. 2005;98:124-5; author reply 5 .

137. Asuquo ME, Ngim O, Ebughe G, Bassey EE. Skin cancers amongst four Nigerian albinos. Int J Dermatol. 2009;48:636-8.

138. van Steensel MA, Jaspers NG, Steijlen PM. A case of Rombo syndrome. Br J Dermatol. 2001:144:1215-8.

139. Ashinoff R, Jacobson M, Belsito DV. Rombo syndrome: a second case report and review. J Am Acad Dermatol. 1993;28:1011-4.

140. Abid K, El Mezni F, Kamoun MR, Fazaa B, Zermani R, Hadouchi C, et al. Xeroderma pigmentosum skin: an immune privilege site for tumor development. J Cutan Pathol 2010;37:452-9.

141. Malhotra AK, Gupta S, Khaitan BK, Verma KK. Multiple basal cell carcinomas in xeroderma pigmentosum treated with imiquimod $5 \%$ cream. Pediatr Dermatol. 2008;25: 488-91

142. Magnaldo T, Sarasin A. Xeroderma pigmentosum: from symptoms and genetics to gene-based skin therapy. Cells Tissues Organs. 2004;177:189-98.

143. Eisen DB, Michael DJ. Sebaceous lesions and their associated syndromes: part I. J Am Acad Dermatol. 2009:61:549-60.

144. Altaykan A, Ersoy-Evans S, Erkin G, Ozkaya O. Basal cell carcinoma arising in nevus sebaceous during childhood. Pediatr Dermatol. 2008;25:616-9.

145. Weinstein A, Nouri K, Bassiri-Tehrani S, Flores F, Jimenez G. Muir-Torre syndrome: a case of this uncommon entity. Int J Dermatol. 2006;45:311-3.

146. Scheper MA, Nikitakis NG, Sarlani E, Sauk JJ, Meiller TF. Cowden syndrome: report of a case with immunohistochemical analysis and review of the literature. Oral Surg Oral Med Oral Pathol Oral Radiol Endod. 2006;101:625-31.

147. Kazakov DV, Zelger B, Rütten A, Vazmitel M, Spagnolo DV, Kacerovska D, et al. Morphologic diversity of malignant neoplasms arising in preexisting spiradenoma, cylindroma, and spiradenocylindroma based on the study of 24 cases, sporadic or occurring in the setting of Brooke-Spiegler syndrome. Am J Surg Pathol. 2009;33:705-19.

148. Szepietowski JC, Wasik F, Szybejko-Machaj G, Bieniek A, Schwartz RA. BrookeSpiegler syndrome. J Eur Acad Dermatol Venereol. 2001;15:346-9.

149. Salhi A, Bornholdt D, Oeffner F, Malik S, Heid E, Happle R, et al. Multiple familial trichoepithelioma caused by mutations in the cylindromatosis tumor suppressor gene. Cancer Res. 2004;64:5113-7.

150. Pincus LB, McCalmont TH, Neuhaus IM, Kasper R, Oh DH. Basal cell carcinomas arising within multiple trichoepitheliomas. J Cutan Pathol. 2008;35Suppl1:59-64.

151. Toyoda M, Morohashi M. Infundibulocystic basal cell carcinoma. Eur J Dermatol. 1998;8:51-3.

152. Kirkup ME, De Berker DA. Clinical measurement of dimensions of basal cell carcinoma: effect of waiting for elective surgery. Br J Dermatol. 1999;141: 876-9.

153. Rieger KE, Linos E, Egbert BM, Swetter SM. Recurrence rates associated with incompletely excised low-risk nonmelanoma skin cancer. J Cutan Pathol 2009 [Epub ahead of print].

154. Bogelund FS, Philipsen PA, Gniadecki R. Factors affecting the recurrence rate of basal cell carcinoma. Acta Derm Venereol. 2007;87:330-4.

155. Nagore E, Grau C, Molinero J, Fortea JM. Positive margins in basal cell carcinoma: relationship to clinical features and recurrence risk. A retrospective study of 248 patients. J Eur Acad Dermatol Venereol. 2003;17:167-70.

156. Goh BK, Ang P, Wu YJ, Goh CL. Characteristics of basal cell carcinoma amongst Asians in Singapore and a comparison between completely and incompletely excised tumors. Int J Dermatol. 2006;45:561-4.

157. Robinson JK, Fisher SG. Recurrent basal cell carcinoma after incomplete resection. Arch Dermatol. 2000;136:1318-24.

158. Martin RC 2nd, Edwards MJ, Cawte TG, Sewell CL, McMasters KM Basosquamous carcinoma: analysis of prognostic factors influencing recurrence. Cancer. 2000;88:1365-9.

159. Bumpous JM, Padhya TA, Barnett SN. Basal cell carcinoma of the head and neck: identification of predictors of recurrence. Ear Nose Throat J. 2000;79:200-2, 4.

160. Griffiths RW, Suvarna SK, Stone J. Do basal cell carcinomas recur after complete conventional surgical excision? Br J Plast Surg. 2005;58:795-805.

161. Griffiths RW, Suvarna SK, Stone J. Basal cell carcinoma histological clearance margins: an analysis of 1539 conventionally excised tumours. Wider still and deeper? J Plast Reconstr Aesthet Surg. 2007;60:41-7.

162. Staub G, Revol M, May P, Bayol JC, Verola 0, Servant JM. Excision skin margin and recurrence rate of skin cancer: a prospective study of 844 cases. Ann Chir Plast Esthet. 2008;53:389-98.

163. Farhi D, Dupin N, Palangié A, Carlotti A, Avril MF. Incomplete excision of basal cell carcinoma: rate and associated factors among 362 consecutive cases. Dermatol Surg. 2007;33:1207-14

164. Rodriguez-Vigil T, Vazquez-Lopez F, Perez-Oliva N. Recurrence rates of primary basal cell carcinoma in facial risk areas treated with curettage and electrodesiccation. J Am Acad Dermatol. 2007;56:91-5.

165. Von Hoff DD, LoRusso PM, Rudin CM, Reddy JC, Yauch RL, Tibes R, et al Inhibition of the hedgehog pathway in advanced basal-cell carcinoma. N Engl J Med. 2009;361:1164-72.

166. Wadhera A, Fazio M, Bricca G, Stanton O. Metastatic basal cell carcinoma: a case report and literature review. How accurate is our incidence data? Dermatol Online J. 2006;12: 7

167. Autier $\mathrm{P}$. Sunscreen abuse for intentional sun exposure. $\mathrm{Br} J$ Dermatol. 2009;161Suppl 3: 40-5.

168. van der Pols JC, Williams GM, Pandeya N, Logan V, Green AC. Prolonged prevention of squamous cell carcinoma of the skin by regular sunscreen use. Cancer Epidemiol Biomarkers Prev. 2006;15:2546-8.

169. Vainio H, Bianchini F. Cancer-preventive effects of sunscreens are uncertain. Scand J Work Environ Health. 2000;26:529-31.

170. King SC, Chen S. Analyzing the cost of preventing nonmelanoma skin cancer J Invest Dermatol. 2009;129:2745-6.

171. Schalka S, dos Reis VM, Cuce LC. The influence of the amount of sunscreen 
applied and its sun protection factor (SPF): evaluation of two sunscreens including the same ingredients at different concentrations. Photodermatol Photoimmunol Photomed. 2009;25:175-80.

172. Rigel DS. Cutaneous ultraviolet exposure and its relationship to the development of skin cancer. J Am Acad Dermatol. 2008;58:S129-32.

173. Ulrich C, Jürgensen JS, Degen A, Hackethal M, Ulrich M, Patel MJ, et al. Prevention of non-melanoma skin cancer in organ transplant patients by regular use of a sunscreen: a 24 months, prospective, case-control study. Br J Dermatol. 2009;161 Suppl 3:78-84.

174. Vainio H, Miller AB, Bianchini F. An international evaluation of the cancer-preventive potential of sunscreens. Int J Cancer. 2000;88:838-42.

175. Gordon LG, Scuffham PA, van der Pols JC, McBride P, Williams GM, Green AC. Regular sunscreen use is a cost-effective approach to skin cancer prevention in subtropical settings. J Invest Dermatol. 2009;129:2766-71.

176. Bath-Hextall F, Leonardi-Bee J, Somchand N, Webster A, Delitt J, Perkins W. Interventions for preventing non-melanoma skin cancers in high-risk groups. Cochrane Database Syst Ver. 2007:CD005414.

177. Kopera D, Cerroni L, Fink-Puches R, Kerl H. Different treatment modalities for the management of a patient with the nevoid basal cell carcinoma syndrome. J Am Acad Dermatol. 1996;34:937-9.

178. Campbell RM, DiGiovanna JJ. Skin cancer chemoprevention with systemic retinoids: an adjunct in the management of selected high-risk patients. Dermatol Ther. 2006;19:306-14

179. Goldberg LH, Hsu SH, Alcalay J. Effectiveness of isotretinoin in preventing the appearance of basal cell carcinomas in basal cell nevus syndrome. J Am Acad Dermatol. 1989;21:144-5.

180. Cristofolini M, Zumiani G, Scappini P, Piscioli F. Aromatic retinoid in the chemoprevention of the progression of nevoid basal-cell carcinoma syndrome. J Dermatol Surg Oncol. 1984;10:778-81.

181. Gerber B, Mathys P, Moser M, Bressoud D, Braun-Fahrländer C. Ultraviolet emission spectra of sunbeds. Photochem Photobiol. 2002;76:664-8.

182. Junkins-Hopkins JM. Tanning and skin cancer. J Am Acad Dermatol. 2010;62:854-6.
183. Robinson JK, Kim J, Rosenbaum S, Ortiz S. Indoor tanning knowledge, attitudes, and behavior among young adults from 1988-2007. Arch Dermatol. 2008;144:484-8.

184. International Agency for Research on Cancer Working Group on artificial ultraviolet (UV) light and skin cancer. The association of use of sunbeds with cutaneous malignant melanoma and other skin cancers: A systematic review. Int J Cancer. 2007;120:1116-22.

185. Bajdik CD, Gallagher RP, Astrakianakis G, Hill GB, Fincham S, McLean DI. Non-solar ultraviolet radiation and the risk of basal and squamous cell skin cancer. Br J Cancer. 1996;73:1612-4.

186. Boyd AS, Shyr Y, King LE Jr. Basal cell carcinoma in young women: an evaluation of the association of tanning bed use and smoking. J Am Acad Dermatol. 2002;46:706-9.

187. Aubry F, MacGibbon B. Risk factors of squamous cell carcinoma of the skin. A case-control study in the Montreal region. Cancer. 1985;55:907-11.

188. Schulman JM, Fisher DE. Indoor ultraviolet tanning and skin cancer: health risks and opportunities. Curr Opin Oncol. 2009;21:144-9.

189. Westerdahl J, Ingvar C, Måsbäck A, Jonsson N, Olsson H. Risk of cutaneous malignant melanoma in relation to use of sunbeds: further evidence for UV-A carcinogenicity. Br J Cancer. 2000;82:1593-9.

190. Ting W, Schultz K, Cac NN, Peterson M, Walling HW. Tanning bed exposure increases the risk of malignant melanoma. Int J Dermatol. 2007;46:1253-7.

191. WHO. Artificial tanning sunbeds - risks and guidance. 1st ed. Geneva, Switzerland: World Health Organization; 2003.

192. Sociedade Brasileira de Dermatologia. Análise de dados das campanhas de prevenção ao câncer da pele promovidas pela Sociedade Brasileira de Dermatologia de 1999 a 2005. An Bras Dermatol. 2006;81: 533-9.

193. Lear W, Mittmann N, Barnes E, Breen D, Murray C. Cost comparisons of managing complex facial basal cell carcinoma: Canadian study. J Cutan Med Surg. 2008;12:82-7.

194. Rhee JS, Matthews BA, Neuburg M, Smith TL, Burzynski M, Nattinger AB. Skin cancer and quality of life: assessment with the Dermatology Life Quality Index. Dermatol Surg. 2004;30:525-9.

\author{
MAILING ADDRESS / ENDEREÇO PARA CORRESPONDENNCIA: \\ Hélio Amante Miot \\ Departamento de Dermatologia - SN \\ Campus Universitário \\ 18618-000 Botucatu - SP, Brazil \\ Tel.: (14) 9671-5656 \\ E-mail: beliomiot@fmb.unesp.br
}

How to cite this article/Como citar este artigo: Miot HA, Chinem VP. Epidemiology of basal cell carcinoma. An Bras Dermatol. 2011;86(2):292-305. 